Володимир Костянтинович Медведєв (канд. військ. наук, професор)

Максим Вікторович Кас'яненко (канд. військ. наук)

Ілона Сераївна Коренівська

Національний університет оборони Украӥни імені Івана Черняховського, Київ, Украӥна

\title{
ПІДХІД ЩОДО ОЦІНЮВАННЯ НАДІЙНОСТІ ФУНКЦІОНУВАННЯ АВТОМАТИЗОВАНОЇ СИСТЕМИ УПРАВЛІННЯ „ОРЕАНДА-ПС”
}

В статті запропоновано методику оцінювання надійності функиіонування автоматизованих систем управління військами (силами) на прикладі автоматизованої системи управління “Ореанда-ПС”, який трунтується на врахуванні незалежності потоку відмов технічних засобів від програмних збоїв та навпаки. Для цьвого проведено декомпозицію вказаної системи за рівнями ієрархї̈ та висвітлено порядок розрахунку надійності функціонування як окремих автоматизованих робочих місиь так $i$ комплексів засобів автоматизації кожного рівня ієрархії. Запропоновано підхід до розрахунку ступеню впливу надійності функціонування кожного комплексу засобів автоматизації на надійність функціонування автоматизованої системи управління в цілому. Крім того,в статті уточнено сукупність часткових показників надійності автоматизованої системи управління, а саме коефіцієнта готовності, ймовірності безвідмовної роботи за час бойового застосування та коефіцієнта оперативної готовності.

Ключові слова: автоматизована система управління, війська, надійність функціонування, показники надійності, коефічієнт готовності, ймовірність безвідмовної робот, коефіцієнт оперативної готовності.

\section{Вступ}

Аналіз розвитку воєнного мистецтва, досвіду війн та збройних конфліктів останніх десятиріч свідчить про те, що в сучасних умовах ведення операцій (бойових дій) все більшого значення набуває фактор досягнення переваги в управління військами. В свою чергу, в провідних країнах світу основним напрямком вдосконалення i розвитку процесу управління військами (силами) є впровадження засобів автоматизації [1].

Використання автоматизованих систем управління (АСУ) дозволяє значно підвищити ефективність застосування сил і засобів всіх видів Збройних Сил (ЗС) України. Особливо це стосується Повітряних Сил, оскільки швидкоплинний та мінливий характер ведення бойових дій (операцій) вимагає адекватних рішень у стислі терміни [2].

Постановка проблеми. Керівництвом держави, ще у середині 2000-х років, було прийнято рішення на розробку і впровадження АСУ авіацією та протиповітряною обороною 3С України - АСУ “Ореанда-ПС”.

Одним 3 найважливіших питань, що вирішувалися і вирішуються на різних стадіях створення і експлуатації АСУ “Ореанда-ПС”, є оцінювання надійності функціонування зазначеної системи та ії елементів в ході бойового застосування.

Тому виникає нагальна потреба у розробленні науково-методичного апарату для оцінювання надійності функціонування КЗА АСУ „Ореанда-ПС”.

Аналіз остатніх досліджень і публікацій. На сторінках наукових видань неодноразово висвітлювались різні моделі та методики щодо визначення надійності функціонування автоматизованих систем управління.

Так, в [3-4] запропоновано методологію оцінювання АCУ 3 урахуванням показників надійності комплексів технічних засобів (Т3), програмного забезпечення (ПЗ), а також відмови, які виникають 3 вини оперативного персоналу (ОП), проте дані підходи не враховують відмови локальної мережі. У статті [5] докладно описано методику розрахунку коефіцієнтів готовності ПЗ та ОП, але запропонований підхід до розрахунку показників надійності для ієрархічних інформаційних систем не може бути використаний для складних АСУ без явно вираженої ієрархії з довільними зв'язками між об'єктами.

Ще одним $з$ підходів, є оцінювання надійності розгалужених АСУ, що грунтується на використанні марковської моделі надійності. У методиці використано аналітичний підхід до оцінювання надійності системи із визначенням 
таких показників надійності, як коефіцієнт готовності та тривалість напрацювання на відмову [6]. Але в даній методиці автором не розглядаються питання оцінки надійності програмного забезпечення та вплив оперативного персоналу на надійність системи.

Проведений аналіз існуючого науковометодичного апарату показав, що існуючі моделі та методики не враховують низки факторів, які на теперішній час суттєво впливають на надійність АСУ, або не охоплюють всіх складових сучасних АСУ. Тому вони не дозволяють 3 необхідною якістю оцінити надійность функціонування АСУ “Ореанда-ПС”.

Таким чином, виникає нагальна потреба в удосконаленні науково-методичного апарату, який би дозволив оцінити надійність функціонування сучасних АСУ, 3 метою вироблення обгрунтованих рекомендацій щодо забезпечення заданого рівня надійності.

Метою статті $\epsilon$ визначення підходу до оцінювання надійності функціонування АСУ „Ореанда-ПС”.

\section{Виклад основного матеріалу дослідження}

Відповідно до тактико-технічного завдання до складу АСУ “Ореанда-ПС” входять багатоцільові комплекси засобів автоматизації (КЗА): “ОреандаЦентр”, “Ореанда-ЗРВ”, “Ореанда-Авіа”,
“Ореанда-РТВ, “Ореанда-РТВ-1”, Ореанда-Р і РЕБ” різних модифікацій, структура якої наведена на рис. 1.

В свою чергу, до складу КЗА входить велика кількість різнорідних елементів: технічні засоби (автоматизовані робочі місця, сервера центрального обчислювального комплексу, комунікаційні сервера, засоби відображення колективного користування, пульти телефонного та гучномовного зв'язку, засоби реєстрації телекодової та мовної інформації, засоби підготовки та друку звітних документів, засоби зв'язку, телекомунікації, криптозахисту тощо) та окремі програмні засоби. Всі зазначені елементи КЗА АСУ “Ореанда-ПС” розгорнуті за мережецентричним принципом. Крім того, КЗА АСУ “Ореанда-ПС” територіально розташовані на значних відстанях один від одного.

Виходячи із вищезазначеного можна стверджувати, що АСУ “Ореанда-ПС” $\epsilon$ надзвичайно складною териториальнорозподіленою багатофункціональною системою, оцінити надійність якої в цілому дуже складно.

Тому для оцінювання надійності АСУ “Ореанда-ПС” доцільно провести ії декомпозицію за рівнями ієрархії (див. Рис. 1)

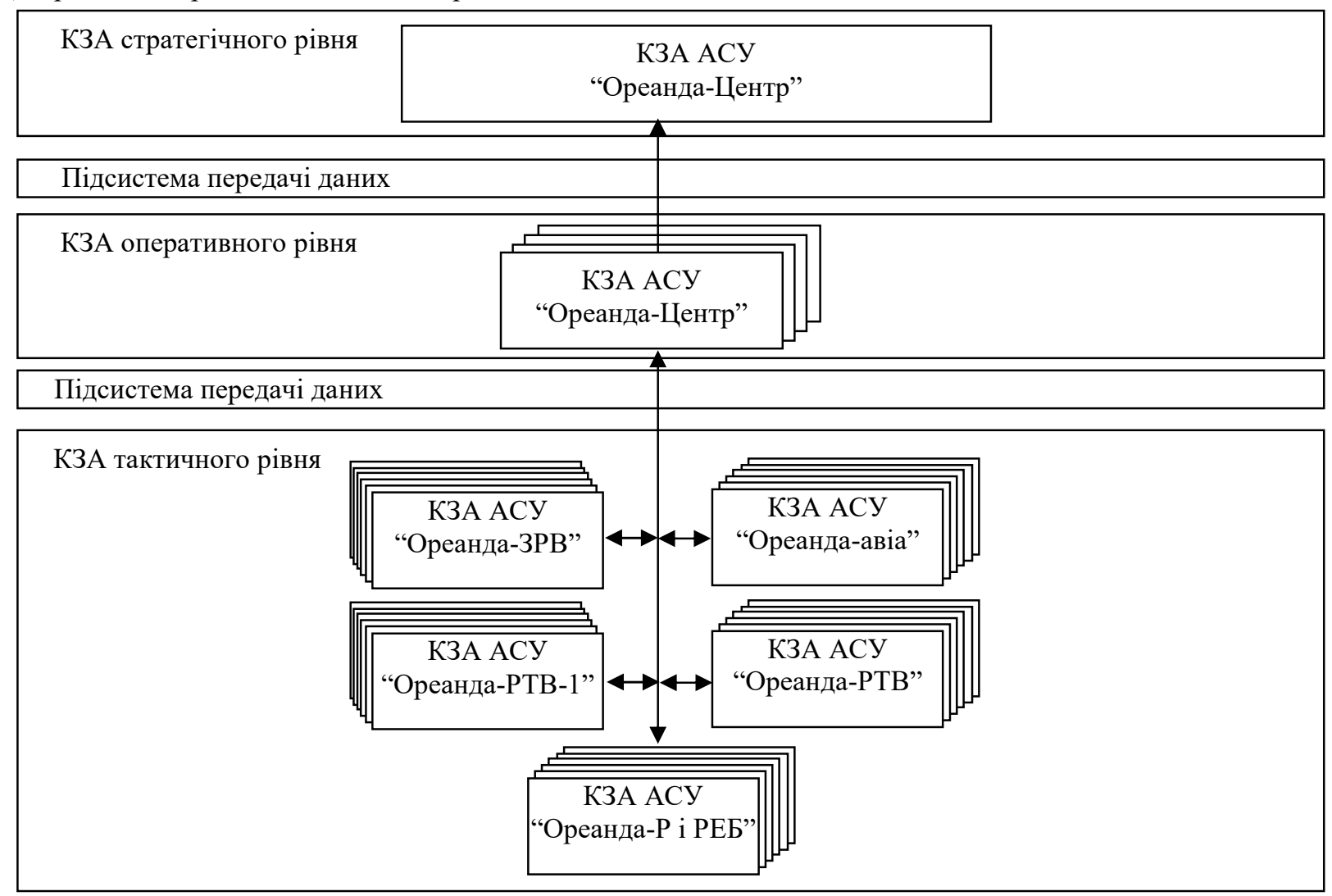

Рис. 1. Декомпозиція АСУ “Ореанда-ПС” за рівнями ієрархії 
Під надійністю будемо розуміти властивість системи зберігати у часі в установлених межах значення всіх параметрів, які характеризують здатність виконувати потрібні функції у визначених режимах та умовах застосування, технічного обслуговування, зберігання та транспортування [2].

Надійність системи, як комплексна властивість, включає в себе: безвідмовність, ремонтопридатність, збережуваність і довговічність.

Разом 3 тим, оскільки в статті розглядається надійність функціонування АСУ “Ореанда-ПС” на етапі експлуатації, то у дослідженні розглянуто дві основні складові надійності: безвідмовність (властивість системи зберігати працездатний стан протягом деякого часу) i ремонтопридатність (пристосованість системи до підтримання та відновлення працездатного стану шляхом технічного обслуговування і ремонту).

Оцінювання безвідмовност

та ремонтопридатності здійснено за наступними ймовірнісними оперативними показниками надійності:

імовірність безвідмовної роботи $P(t) \quad-$ ймовірність того, що система буде працездатна протягом заданого часу роботи при заданих умовах експлуатації. Даний показник дає можливість для оцінювання безвідмовності системи під час іiі бойового застосування (тобто, коли АСУ використовується за своїм основним призначенням);

коефіцієнт готовності $K_{\Gamma^{-}}$ймовірність того, що система виявиться в працездатному стані в довільний момент часу. Це характеристика системи, яка характеризується показниками ремонтопридатності: $T_{0}-$ середній час напрацювання на відмову i $T_{B}$ - середній час відновлення після відмови. Оскільки часу на ремонт елементів системи, що відмовили, під час бойовий дій немає, то цей показник оцінює ймовірність працездатності системи в довільний момент часу;

коефіцієнт оперативної готовності $K_{O \Gamma}(t)-$ ймовірність того, що система виявиться працездатною в довільний момент часу, i, починаючи $з$ цього моменту, буде працездатною ще протягом заданого часу. Це також комплексна характеристика безвідмовності i ремонтопридатності системи. У нашому випадку $K_{O \Gamma}(t)$ характеризує ймовірність виконання системою свого основного завдання під час бойового застосування 3 урахуванням того, що система буде в працездатному стані в момент початку бойового застосування.

Для проведення подальших розрахунків введено поняття - елемент надійності, під яким розуміємо:

для розрахунку надійності АРМ сукупність ТЗ та ПЗ;

для розрахунку надійності КЗА сукупність АРМ, що входять в його склад;

для розрахунку надійності в цілому сукупність КЗА відповідного рівня.

На кожному рівні (стратегічному, оперативному, тактичному) КЗА складаються 3 певної кількості АРМ, які умовно можна розділити на АРМ трьох типів: АРМ оперативного складу (OC), АРM серверу центрального обчислювального комплексу (СЦОК) та АРМ комунікаційного серверу (КС).

Тоді коефіцієнт готовності КЗА певного рівня $\left(K_{\Gamma}\right)$ можливо визначити за допомогою виразу:

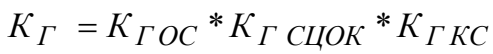

де $K_{\Gamma ~}$ оC - коефіцієнт готовності АРМ ОС;

$K_{Г \text { СцОК }}-$ коефіцієнт готовності АРМ СЦОК;

$K_{Г К С ~}-$ коефіцієнт готовності АРМ КС.

3 метою врахування імовірнісного переходу певної кількості АРМ 3 працездатного у непрацездатний стан та навпаки протягом бойового застосування та розрахунку надійності функціонування АСУ у будь-який час операції використаємо теорію ймовірності.

Враховуючи те, що відмова окремих АРМ не призводить до втрати працездатності всього КЗА (АРМ одного типу можуть дублюватися АРМ того ж типу), але знижує ефективність його функціонування, що $є$ критичною під час виконання бойового завдання, тому загальну надійність функціонування типового АРМ (АРМ OC, АРМ ЦСОК або АРM СК) $\left(K_{\Gamma T}\right)$ можна розрахувати за виразом:

$$
K_{\Gamma T}=\sum_{m=1}^{n} \frac{C_{n}^{m} k_{2}^{m}\left(1-k_{2}\right)^{n-m}}{\sum_{l=1}^{n} C_{n}^{l}},
$$

де $k_{2}$ - коефіцієнт готовності одного АРМ;

$n$ - кількість АРМ одного типу;

$m$ - кількість працездатних АРМ одного типу;

$l-1 \ldots m$;

$C_{n}^{m}=\frac{n !}{m !(n-m) !}-$ біноміальний коефіцієнт;

$C_{n}^{l}=\frac{n !}{l !(n-l) !}-$ біноміальний коефіцієнт. 
Використовуючи вираз (1) та (2) тактичного рівня, за виразом: визначається коефіцієнт готовності КЗА

$$
\begin{aligned}
& K_{\Gamma T P}=K_{\Gamma O C} * K_{\Gamma С Ц O K} * K_{\Gamma K C}=\sum_{n_{o c}=1}^{m_{o c}} \frac{C_{n_{o c}}^{m_{o c}} K_{\Gamma O C m_{o c}}{ }^{m_{o c}}\left(1-K_{\Gamma O C m_{o c}}\right)^{n_{o c}-m_{o c}}}{\sum_{l_{o c}=1}^{n_{o c}} C_{n_{o c}}^{l_{o c}}} *
\end{aligned}
$$

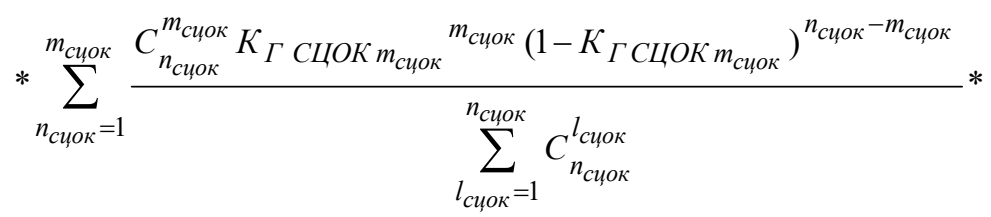

$$
\begin{aligned}
& * \sum_{n_{\kappa c}=1}^{m_{\kappa c}} \frac{C_{n_{\kappa c}}^{m_{\kappa c}} K_{\Gamma K C m_{\kappa c}} m_{\kappa c}\left(1-K_{\Gamma A P M K C m_{\kappa c}}\right)^{n_{\kappa c}-m_{\kappa c}}}{\sum_{l_{\kappa c}=1}^{n_{\kappa c}} C_{n_{\kappa c}}^{l_{\kappa c}}}
\end{aligned}
$$

де $n_{\text {оc }}, n_{\text {сиок }}, n_{\kappa c}-$ загальна кількість відповідних типових АРМ;

$$
m_{o c}, m_{\text {сиок }}, m_{\kappa c}-\text { кількість працездатних }
$$

АРМ певного типу;

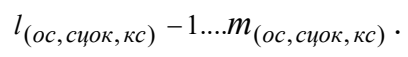

Як видно з виразу (3), відмову одного 3 АРМ певного типу не можна вважати відмовою для КЗА тактичного рівня (інший АРМ цього типу виконує функції АРМ, який відмовив). При цьому КЗА продовжить виконувати свої функції. Разом 3 тим, відмова усіх АРМ одного типу буде означати відмову всього КЗА.
Повна відмова АСУ в цілому виникає 3 виходом 3 ладу всіх КЗА тактичного рівня одночасно. У той же час, вихід з ладу одного або декількох КЗА тактичного рівня призводить до часткової втрати працездатності, але не до відмови системи в цілому.

Аналогічно коефіцієнту готовності розраховується і ймовірність безвідмовної роботи $P(t) \quad$ (шляхом добутку показників $P(t)$ відповідних елементів надійності (аналогічно формулі (3))

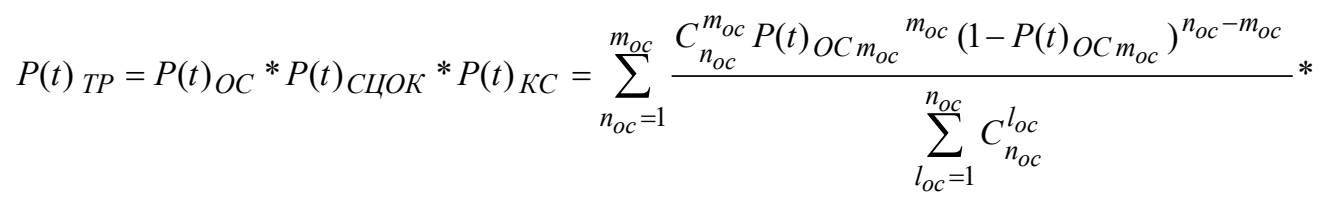

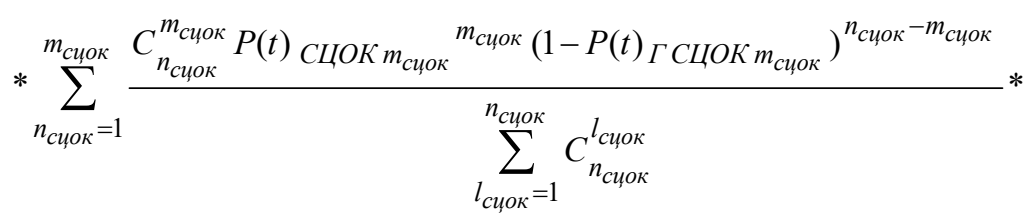

$$
\begin{aligned}
& * \sum_{n_{\kappa c}=1}^{m_{\kappa c}} \frac{C_{n_{\kappa c}}^{m_{\kappa c}} P(t)_{K C m_{\kappa c}}^{m_{\kappa c}}\left(1-P(t)_{K C m_{\kappa c}}\right)^{n_{\kappa c}-m_{\kappa c}}}{\sum_{l_{\kappa c}=1}^{n_{\kappa c}} C_{n_{\kappa c}}^{l_{\kappa c}}}
\end{aligned}
$$

Враховуючи вирази (3) та (4) коефіцієнт оперативної готовності розраховується за виразом:

$$
K_{O Г T P}(t)=K_{\Gamma T P} P(t)_{T P}
$$

Оскільки КЗА оперативного і стратегічного рівнів 3 точки зору теорії надійності не відрізняються від АРМ тактичного рівня, то коефіцієнт готовності, ймовірність безвідмовної роботи та коефіцієнт оперативної роботи розраховуються аналогічно показникам надійності КЗА тактичного рівня.
Виходячи 3 того, що на оперативному та стратегічному рівнях КЗА можуть бути взаємозамінними, тобто КЗА стратегічного рівня, за необхідності, може бути замінене КЗА оперативного рівня, що, в свою чергу, може вплинути на надійність функціонування КЗА оперативного рівня, коефіцієнт готовності АСУ

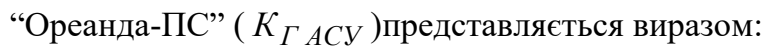

$$
K_{\Gamma A C Y}=\min \left\{K_{\Gamma T P}, \frac{K_{\Gamma O P}+K_{\Gamma C P}}{2}\right\},
$$


Попередні дослідження свідчать, що розрахувати надійність такої територіальнорозподіленої АСУ, як АСУ „Ореанда-ПС”, неможливо без врахування надійності каналів зв'язку, Т3 та ПЗ, що відносяться до підсистеми передачі даних (ПСПД). При цьому необхідно врахувати, що відмови всіх каналів зв'язку, що зв'язують КЗА тактичного і оперативного рівнів, будуть рівнозначні виходу 3 ладу всіх КЗА тактичного рівня. Вихід з ладу каналів зв'язку в КЗА оперативного і стратегічного рівнів, буде рівнозначний виходу 3 ладу всіх КЗА оперативного рівня (відповідно і всіх підпорядкованих йому КЗА тактичного рівня).

Таким чином, можна стверджувати, що від роботи ПСПД залежить надійність функціонування АСУ у визначений часовий проміжок.

Крім того, людина, як ланка системи, має такі властивості: здатність до адаптації, здатність до втомлюваності, здатність до відпочинку,

\section{Лimepamypa}

1. Осборн К. (2018), Військово-Повітряні Сили створюють систему управління збройними силами у війні [The National Interest]: https://nationalinterest.org/blog/the - buzz/the-air-force creating - system-manage - the-militarys-forces-24701. 2. Нізієнко Б. Основні напрямки автоматизації процесів управління в Повітряних Силах Збройних Сил України. - M .: Збірник наукових праць Харківського національного університету Повітряних Сил, 2017 -. - 19 с. 3. ДСТУ 3524-97. Надійність техніки. Проектна оцінка надійності складних систем 3 урахуванням можливість здійснення помилки, здатність приймати рішення, здатність запам'ятовування інформації, здатність переносити інформаційну перевантаження тощо [4]. Тому вплив людського фактору на надійність АСУ „Ореанда-ПС” також $\epsilon$ вкрай важливим.

\section{Висновки й перспективи подальших досліджень}

Запропонований підхід на відміну від [5] враховує територіальну розподіленість і ієрархічність системи, що дозволить більш адекватно оцінити надійність функціонування АСУ “Ореанда-ПС”.

Завданням подальшого дослідження може буде визначення підходів щодо врахування надійності ПСПД та впливу людського фактору на надійність АСУ „Ореанда-ПС” в цілому.

технічного і програмного забезпечення та оперативного персоналу. Основні положення. - К.: Держстандарт України, 1994.- 36 с. 4. ДСТУ 2862-94. Надійність техніки. Методи розрахунку показників надійності. Загальні вимоги. - К.:Держстандарт України, 1994. - 36 c. 5. Гришко В., Можаровський П. Оцінка надійності комплексу технічних засобів складних інформаційноуправляючих систем. - М : Математичні машини i системи, 2009. № 3- 194 с. 6. Акімова Г., Соловйов А, Методологія оцінювання надійності ієрархічних інформаційних систем, М. Труди ІСА РАН, 2006 - 18 с.

\title{
ПОДХОД К ОЦЕНИВАНИЮ НАДЕЖНОСТИ ФУНКЦИОНИРОВАНИЯ АВТОМАТИЗИРОВАННОЙ СИСТЕМЫ УПРАВЛЕНИЯ "ОРЕАНДА-ПС
}

\author{
Владимир Константинович Медведев (канд. воен. наук, профессор) \\ Максим Викторович Касьяненко (канд. воен. наук) \\ Илона Сергеевна Коренивская
}

\section{Национальный университет обороны Украины имени Ивана Черняховского, Киев, Украина}

В статье предложен подход к оиениванию надежности функиионирования автоматизированных систем управления войсками (силами) на примере автоматизированной системы управления "ОреандаПС", основанный на учете независимости потока отказов технических средств от программных сбоев и наоборот. Для этого проведено декомпозицию указанной системы по уровням иерархии и отражен порядок расчета надежности функиионирования, как отдельных автоматизированных рабочих мест, так и комплексов средств автоматизации каждого уровня иерархии. Предложен подход к расчету степени влияния надежности функционирования каждого комплекса средств автоматизации на надежность функционирования автоматизированной системы управления в целом. Кроме того, в статье уточнена совокупность частных показателей надежности автоматизированной системы управления, а именно коэффициента готовности, вероятности безотказной работь за время боевого применения и коэффициента оперативной готовности.

Ключевые слова: автоматизированная система управления, войска, надежность функиионирования, показатели надежности, коэффициент готовности, вероятность безотказной работы, коэффиичиент оперативной готовности. 


\section{THE APPROACH TO EVALUATION AUTOMATED MANAGEMENT SYSTEM OF OREANDA-PS RELIABILITY}

Volodymyr K. Medvedev (Candidate of Military Sciences, professor) Maksym V. Kasyanenko (Candidate of Military Sciences) Ilona S. Korenivska

\section{National Defence University of Ukraine named after Ivan Cherniakhovsky, Kyiv, Ukraine}

The article deals with a state-of-the-art approach to assess troops (forces) automated control systems the reliability. It finds its practical application on the automated control system "Oreanda-PS". It relies on isolated hardware failures resulting from software crashes. Hence that we have carried out the specified system decomposition in accordance with the hierarchy system. In addition, we have accomplished certain procedure to calculate individual workstations reliability. Along with this, we have develop automatic fire control system on each hierarchy level. A new approach to calculate impact level on each automated control system reliability in general. Moreover, a set of the automated control system partial indicators has been singled out, such as: availability factor, consistent operation probability, and the operational availability index.

Keywords: automated control system, reliability, indicator, availability factor, consistent operation probability, operational availability.

\section{References}

1. Osborn K. (2018), The Air Force Is Creating a System to Manage the Military's Forces in War [The National Interest], available at: https://nationalinterest.org/blog/thebuzz/the-air-force-creating-system-manage-the-militarysforces-24701. 2. Nizienko B. (2017), The Main Directions of Automation of Management Processes in the Air Force of Ukraine. [Scientific Works of Kharkiv National Air Force University], Kharkiv:, 19 p. 3. DSTU 3524-97. The reliability of technology. Project assessment of the reliability of complex systems, taking into account the technical and software operational staff. Substantive provisions. - K.:
Gosstandart of Ukraine, 1994.- 36 p 4. DSTU 2862-94. Reliability of technology. Methods of calculating reliability indices. General requirements. - K .: Gosstandart of Ukraine, 1994. - 36 p.5. Gryshko V., Mozharovsky P., (2009), The Estimation of Reliability of Complex of Technical Means of Complex Information Control Systems. [Mathematical Machines and Systems]. 6. Akimova G., Solovyov A. (2006), Methodology for evaluating the reliability of hierarchical information systems. [Papers ISA RAN], Moscow, 18 p. 